\title{
ACKNOWLEDGMENTS
}

\footnotetext{
$T_{h}$
}

he process of completing this book was a long labor of love, hard work, and personal sacrifice. Although at times it was an intensely lonely and isolating practice, it could not have been completed without the love and support of many people. I wish to convey my enormous gratitude to those who have played an important role in the formulation and completion of this journey.

Much of this work was inspired by scholars at the Joint Medical Anthropology Program at the University of California, San Francisco and Berkeley, who taught me to think and act in ways that I never dreamed possible. I am particularly thankful to Vincanne Adams, who has always pushed me to think beyond the levels of conventional theoretical paradigms, for providing such valuable advice long after my formal studies ended. I would like to thank Yewoubdar Beyene, Sharon Kaufman, and Edwina Newsom for ensuring that funding was available for this research and for providing much-needed support after the untimely death of Gay Becker.

My growth as a scholar and a person would not have been possible without the late Gay Becker. Her intelligence, unwavering support, and positive attitude was always a source of strength for me. Her passion and dedication to her research and lifework closely mirrored her conduct as a mentor. In other words, she was the same person both inside and outside the classroom, in and out of the research context. She was an exceptional person who devoted a great deal of thought and time to others. My gratitude and admiration for her is beyond words.

In addition, I am highly indebted to Philippe Bourgois. His astute recognition of the problems of ethnographic research has taught me to become a better scholar and, more important, a critically engaged person in the world. Furthermore, he has steadfastly reminded me of the importance of voicing my own reservations and struggles in bringing seemingly disparate theoretical strands of scholarship together. Without his support, I would not have been as confident in asserting the benefits of dialogue between studies in public health, science and technology studies, and critical medical anthropology. 
Charis Thompson also provided invaluable support as teacher and guide. She always made me feel comfortable and normal whenever I doubted myself, and she gave me the encouragement to move forward whenever I felt stuck.

No one has played as great a role in inspiring this work as Charles Briggs. Although our relationship began as a leap of faith toward the very end of my fieldwork in South Florida, his intellectual vision and rigor motivated me to think and work beyond what I thought were the limits of my abilities. His brilliance never kept him from being an exceptional teacher and friend, and his astute understanding of the complexities of my research continually inspires me to work and think harder. I will always be thankful for his generous and unwavering support and friendship.

Likewise, in Miami, I would like to thank those with whom I worked at the Haitian Summer Institute at Florida International University, particularly Jacques Pierre. My research could not have progressed nearly as well as it did without my institutional affiliation with the University of Miami and the informal discussions I had with J. Bryan Page and Edward LiPuma. Most of all, I am thankful for the mentorship of Louis H. Marcelin at the University of Miami. His limitless support helped me get my foot in many doors, and his intellectual and methodological rigor alleviated the many struggles that I encountered during fieldwork in Miami and with various Haitian communities. In addition, for the first time in my life, I was able to speak honestly with an anthropologist who, like me, confronts the daily realities of being a racial and ethnic minority in a discipline that often turns a blind eye to its past and continuing legacies of marginalization. His strength, humility, and perseverance personally and professionally in the face of hardship has been a true inspiration in all aspects of my life.

I must also mention how much my life and work have been deeply enriched by Ben Hickler, Ippolytos Kalofonos, Jennifer Liu, and Betsy Pohlman. They have given and continue to give me the kind of intimate support that only people in the same situation can do. I am deeply indebted to them and others, including Alex Choby, Johanna Crane, Beverly Davenport, Robin Higashi, Saida Hodzic, Seth Holmes, Yoshiko Konishi, and Simon Lee, for all the years of intellectual stimulation and hearty laughter. Likewise, Kristin Bright, Lauren Fordyce, Richard Giosio, and Suzanne Carroll Woodard provided me with invaluable friendship throughout my fieldwork in Miami.

I also want to thank Peter Brown, Svea Closser, Douglas Feldman, David Malebranche, and Ann Russ, who welcomed me as a colleague and helped in the writing process during my years in Atlanta and Rochester, New York. I am particularly indebted to the cohorts of students from my Anthropology of Global HIV/AIDS seminar at Emory University's Global Health, Culture, and Society program. During a time when I felt disheartened about the future of HIV/AIDS 
research in governmental public health agencies, these young people inspired me in many ways. Thank you for your collegiality, intense curiosity, and unfettered idealism. Although you may have not have known it, you made me fall in love with my work again.

I am also indebted to colleagues at the Centers for Disease Control and Prevention (CDC), particularly those at the National Center for HIV/AIDS, Viral Hepatitis, Sexually Transmitted Diseases, and Tuberculosis Prevention. To say that my time at the CDC was a life-changing experience would be an understatement. I began my three-year tenure there with the expectation of infusing ethnography into public health prevention methods. I soon realized that I needed to start the conversation at an earlier stage, beginning with the usefulness of mixed methods before moving on to qualitative or ethnographic work. Spending an enormous amount of time in long daily meetings, writing administrative reports, and conceptualizing policy papers often seemed overwhelming and pointless at the time, but I realize now how much this experience has added to my life, both personally and professionally. I want to thank Fred Bloom, Mahnaz Charania, Hazel Dean, Audrey Dowling, Kevin Fenton, Jessie Ford, Zanetta Gant, Kathleen McDavid Harrison, Matthew Hogben, Megan Ivankovich, David Johnson, William E. Jones, Yzette Lanier, Tanya LeBlanc, Penny Loosier, Reshma Mahendra, Donna McCree, Eleanor McLellan, Greg Millett, Ramal Moonesinghe, Ranell Myles, Thomas Painter, Laurie C. Reid, Karen Resha, Rebecca Schmidt, Sonia Singh, Angela M. Smith, Madeleine Sutton, Bindu Tharian, Jo Valentine, Petra Vallila-Buchman, Mary Vernon-Smiley, Mikel Walters, and Samantha Williams for teaching me a tremendous amount about the true meaning of collaboration and partnerships. I have learned a great deal about how to think practically, speak and write clearly, and work with various constituents and within the constraints of severely limited resources. I appreciate and will apply these valuable lessons in various aspects of my life.

I want to single out a few people at the CDC in particular. First, I am indebted to Karen Kroeger and Kim Williams for the endless guidance and support that they have given me. Karen taught me by example how to be an effective anthropologist in the rough seas of public health at governmental agencies, and Kim modeled the virtues of patience, humility, and perseverance in the face of incessant expectations and rigid deadlines. I want to thank Eleanor Fleming, Tracey Hardy, and Puja Seth for their friendship and the many tears and laughter that we have shared together. I will always cherish our time together.

At the University of Maryland, College Park, I am grateful for the Department of Anthropology's continued support. Thank you for giving me the freedom to write.

I want to express my sincere gratitude to my writing partners for the past two years: Adia Benton and Jennifer Liu. Without their support, guidance, and 
friendship, this manuscript would not be where it is today. Thank you for seeing things that I did not and for pushing me to think of my work as a useful intervention. I look forward to many years of working together.

This study would not have been possible without the generous institutional and financial support of the National Institute on Aging and the National Institute on Minority Health and Health Disparities at the National Institutes of Health, the Association of Prevention Teaching and Research, the Oak Ridge Institute for Science and Education, Sigma Xi, USA Funds Access to Education, the US Department of Education's Foreign Language and Area Studies Program, and the University of California, San Francisco.

I am indebted to Peter Mickulas for seeing this book through to publication and to the rest of the helpful staff at of Rutgers University Press. The comments I received from external reviewers and copyeditors were extremely valuable and helped make the narrative more accessible to a wider audience. I would also like to thank the Taylor \& Francis Group for the permission to expand on my article "Treating the Numbers: HIV/AIDS Surveillance, Subjectivity, and Risk," in Medical Anthropology 31 (4) (2012).

Most important, I am humbled by the generosity of spirit of the people who allowed me into their lives in Miami. It is never easy to have a stranger hanging around, trying to insert herself into one's daily routine, and I am very thankful to the many men and women who shared their stories of struggle and joy with me. Although their names must remain anonymous for reasons of confidentiality, they are by no means nameless or anonymous in my thoughts and gratitude. I am particularly grateful to three wonderful women who wish to remain anonymous, who took me into their lives and treated me like a daughter. Anthropological fieldwork can be isolating, but I always stayed focused and grounded through the familial relationships that these women provided. Their gratitude, humor, and love for life through some of the most tragic situations I have ever witnessed put things into proper perspective and taught me life lessons that I could not have possibly learned in government offices or ivory towers.

I am also indebted to Eddie Jean Baptiste, Marlene Bastien, Frank Dardompre, Stanley Denis, Hudes Desrameaux, Katiana Diaz, Jeline Fertil, Leoni Hermatin, Dushyantha T. Jayaweera, Marie D. Jervais, Ketty Ledan, Regine Lefevre, Georges Metellus, Gepsie Mettelus, Christina Morrow, Francis Penha, Juan Carlos Riascos, Kwesi Rose, Marie Saintus, Kira Villamizar, and countless others working to better the lives of Haitians everywhere. Their tireless dedication to improving the lives of so many people who live in despair and destitution is truly remarkable, and their deep understanding of the problems of public health interventions forced me to reexamine the limits of my own questions and to rearticulate new intellectual boundaries. 
This book would not have been possible without support from my immediate and extended family and friends. Thank you for cheering me on from the sidelines and for putting up with my inability to keep in better touch. I am most indebted to my husband, James Cerwinski, who has endured the many years of incessant drama that comes with my involvement in the academy. It is not easy to prioritize a partner's research, writing, and teaching needs in the face of the daily struggles that come with an equally demanding career, unexpected economic challenges, raising two children, and a cross-country move. But he did it all with endless patience and humor. I also would like to thank the two other most important people in my life, Gyan and Ashok, for putting up with a mother who is still trying her best to negotiate shifting priorities. Your endless energy and curiosity inspire me every day. I am so excited to watch you learn, grow, and explore the world.

Finally, my parents, Nala and Kathirethamby Sangaramoorthy, deserve a special note of gratitude. Almost thirty years ago, they miraculously managed to leave Sri Lanka days before the Colombo riots with about a hundred dollars in their pockets. They left relatives, livelihoods, and material belongings behind in order to begin a new life for their children. They worked around the clock, sacrificing their own educational and professional dreams to give their daughters a chance at something better. Their achievements are mine, and mine are theirs. 



\section{Treating AIDS}


